\title{
Mechanical properties of NiTi and CuNiTi shape-memory wires used in orthodontic treatment. Part 1: Stress-strain tests
}

Marco Abdo Gravina¹, Ione Helena Vieira Portella Brunharo², Cristiane Canavarro³, Carlos Nelson Elias ${ }^{4}$ Cátia Cardoso Abdo Quintão ${ }^{5}$

Objective: This research aimed to compare, through traction tests, eight types of superelastic and heat-activated NiTi archwires, by six trade companies (GAC, TP, Ormco, Masel, Morelli and Unitek) to those with addition of copper $\left(\mathrm{CuNiTi} 27^{\circ} \mathrm{C}\right.$ and $35^{\circ} \mathrm{C}$, Ormco). Methods: The tests were performed in an EMIC mechanical testing machine, model DL10000, capacity of 10 tons, at the Military Institute of Engineering (IME). Results: The results showed that, generally, heat-activated NiTi archwires presented slighter deactivation loadings in relation to superelastic. Among the archwires that presented deactivation loadings biologically more adequate are the heat-activated by GAC and by Unitek. Among the superelastic $\mathrm{NiTi}$, the $\mathrm{CuNiTi} 27^{\circ} \mathrm{C}$ by Ormco were the ones that presented slighter deactivation loadings, being statistically (ANOVA) similar, to the ones presented by the heat-activated NiTi archwires by Unitek. When compared the $\mathrm{CuNiTi} 27^{\circ} \mathrm{C}$ and $35^{\circ} \mathrm{C}$ archwires, it was observed that the $27^{\circ} \mathrm{C}$ presented deactivation forces of, nearly, $1 / 3$ of the presented by the $35^{\circ} \mathrm{C}$. Conclusion: It was concluded that the $\mathrm{CuNiTi} 35^{\circ} \mathrm{C}$ archwires presented deactivation loadings biologically less favorable in relation to the other heat-activated NiTi archwires, associated to lower percentage of deformation, on the constant baselines of deactivation, showing less adequate mechanical behavior, under traction, in relation to the other archwires.

Keywords: Orthodontic archwires. Dental movement. Copper. Nickel. Titanium. Physical properties.

Objetivo: o objetivo dessa pesquisa foi comparar, por meio de ensaios de tração, oito tipos de fios de NiTi superelásticos e termoativados, de seis empresas comerciais (GAC, TP, Ormco, Masel, Morelli e Unitek) àqueles com adição de cobre (CuNiTi $27^{\circ} \mathrm{C}$ e $35^{\circ} \mathrm{C}$, da ORMCO). Métodos: os ensaios foram realizados em máquina de ensaios mecânicos, da marca EMIC, modelo DL10000, de 10 toneladas de capacidade, no Instituto Militar de Engenharia (IME). Resultados: os resultados mostraram que, de forma geral, os fios de NiTi termoativados apresentaram cargas mais suaves de desativação que os superelásticos. Entre os fios que apresentaram as cargas de desativação biologicamente mais adequadas, estão os termoativados da GAC e da Unitek. Entre os fios de NiTi superelásticos, os de CuNiTi $27^{\circ} \mathrm{C}$ da Ormco foram os que apresentaram as cargas mais suaves de desativação, sendo estatisticamente semelhantes (ANOVA) às apresentadas pelos fios de NiTi termoativados da Unitek. Quando comparados os fios de $\mathrm{CuNiTi} 27^{\circ} \mathrm{C}$ aos de $35^{\circ} \mathrm{C}$, observou-se que os primeiros apresentaram forças de desativação de, aproximadamente, $1 / 3$ das apresentadas pelos últimos. Conclusão: conclui-se que os fios de $\mathrm{CuNiTi} 35^{\circ} \mathrm{C}$ apresentaram cargas de desativação biologicamente menos favoráveis em relação aos demais fios de NiTi termoativados, sendo associadas a percentuais inferiores de deformação, nos patamares constantes de desativação, demonstrando comportamento mecânico, sob tração, menos adequado em relação aos demais fios.

Palavras-chave: Fios ortodônticos. Movimentação dentária. Cobre. Níquel. Titânio. Propriedades físicas.

${ }^{1}$ Assistant Professor of Orthodontics, UFJF.

${ }^{2}$ Visiting Professor of Orthodontics, FOUERJ.

${ }^{3}$ Substitute Professor of Orthodontics, FOUERJ.

${ }^{4}$ Assistant Professor of the Military Institute of Engineering (IME).

${ }^{5}$ Assistant Professor of Orthodontics, FOUERJ.

" The authors report no commercial, proprietary or financial interest in the products or companies described in this article.
How to cite this article: Gravina MA, Brunharo IHVP, Canavarro C, Elias $\mathrm{CN}$, Quintão CCA. Mechanical properties of $\mathrm{NiTi}$ and CuNiTi shape-memory wires used in orthodontic treatment. Part 1: Stress-strain tests. Dental Press J Orthod. 2013 July-Aug;18 (4):35-42.

Submitted: July 31, 2009 - Revised and accepted: August 09, 2010

Contact address: Marco Abdo Gravina

Av. Barão do Rio Branco, 2595 - Sala 1204 - Juiz de Fora/MG - Brazil CEP: 36010-011 - E-mail: marcoabdogravina@yahoo.com.br 


\section{INTRODUCTION}

The tooth alignment and leveling constitute the preliminary clinical phase of any orthodontic procedure with fixed appliances. ${ }^{8}$ It has been accepted in orthodontics the principle that slight and continuous forces would be desirable for obtainment of physiologic and controlled tooth movement. For this purpose, it has been suggested the superelastic and heatactivated nickel-titanium (NiTi) archwires, which offer a force-bending curve with a defined baseline and a larger activation range..$^{5,6,11}$

Despite the small number of available alloys for manufacture of orthodontic archwires, there is a large number of trade brands of available archwires. The manufacturing companies invest in advertising calling the archwires superior (superelastic and heat-activated NiTi) and emphasize that they provide better performance due to the appropriate mechanical properties. However, these properties not always are described on the product package. Thus, the variety of brands, the large number of manufacturing companies and the lack of information about the material properties make it difficult for the professional to choose the most adequate material and with better cost-benefit for use. ${ }^{11,22}$

Some mechanical properties of orthodontic archwires, such as high resilience, low elasticity module, high flexibility, high elastic recovery, low coefficient of attrition and biocompatibility, are necessary in order to stimulate the adequate tissue response $\mathrm{e}^{1,4,15,17,19}$ and promote slight and continuous forces during the tooth leveling and alignment. ${ }^{9,30}$ However, to quantify the ideal force becomes difficult due to individual variations on the tissue response, to root morphology and to type of induced movement. ${ }^{9}$ Rock and Wilson ${ }^{23}$ asserted that there is a consensus that the ideal orthodontic forces should vary between 15 and 500 gf.

The superelastic NiTi archwires were commercially launched in 1986 (Japanese NiTi and Chinese $\mathrm{NiTi}$. In vitro studies showed that such alloys had excellent elastic properties and generated constant forces, when subjected to loadings, even before the increase on deformation. This made the archwires extremely popular for the use in tooth leveling and alignment. ${ }^{8}$ The heat-activated NiTi alloys emerged commercially in the 90's. Besides the properties of maintenance of constant loadings during loading and unloading, the heat dynamic NiTi archwires showed shape memory thermally induced, presenting ductility and malleability in lower temperatures returning to the initial configuration, when heated to higher temperatures than their transition temperature. ${ }^{16,20}$

According to Sachdeva, ${ }^{25} \mathrm{NiTi}$ archwires with addition of copper (CuNiTi) appeared in the 90's and are composed, basically, of nickel, titanium, copper and chromium. For presenting addition of copper (efficient heat conductor) to nickel and titanium, they would present better defined transition temperatures, which would ensure the generation of more homogeneous loadings from arch to arch and from end to end, increasing the effectiveness on tooth movement. They were introduced in the market by Ormco Corporation with three transition temperatures: $27^{\circ} \mathrm{C}, 35^{\circ} \mathrm{C}$ and $40^{\circ} \mathrm{C}$, enabling to clinicians the quantification and application of levels of adequate loadings to the initial purposes of the orthodontic treatment. When compared to the conventional heat-activated and superelastic NiTi archwires, the CuNiTi archwires would present, still, lower elasticity module, i.e., they would experience similar deformations, before lower activation loadings, presenting a high capacity to fit to brackets of misplaced teeth, with less discomfort to the patient and lower potential to generate tooth resorption. Besides, they would present reduced hysteresis, which would ensure the production of more constant forces and for longer periods of time during deactivation, factors biologically favorable to tooth movement. ${ }^{25}$

Because of existing gaps in publications related to comparison of mechanical behavior of $\mathrm{NiTi}$ and $\mathrm{Cu}-$ $\mathrm{NiTi}$ archwires, it is the objective of the present work to determine and compare some of the mechanical properties, in tests of resistance to traction, presented by the conventional superelastic and heat-activated orthodontic archwires, by different trade brands, to the presented by the NiTi archwires with addition of copper $\left(\mathrm{CuNiTi} 27^{\circ} \mathrm{C}\right.$ and $\left.35^{\circ} \mathrm{C}\right)$.

\section{MATERIAL AND METHODS}

Sixty orthodontic archwires were used, 0.018-in, precontoured and with the same arch shape. According to the mechanical properties provided by the manufacturers, the archwires were divided into two groups (Table 1).

The mechanical properties of the archwires were determined from the tests of resistance to traction, performed in EMIC mechanical testing machine, 
model DL10000, capacity of 10 tons (EMIC International Corp., Garland, USA) (Fig 1A), at the Military Institute of Engineering (IME), Rio de Janeiro. It was used a $500 \mathrm{~N}$ cell (50 kgf) and testing speed of $1 \mathrm{~mm}$ of deformation per minute.

The archwires were positioned in the testing machine, as obtained at the store. Initially, it was applied a slight force so the portion of wire positioned between the machine's nails became straight (Fig 1B).

First, three specimens from each subgroup of archwires were stretched until break to determine their yield stress and constant baselines of activation. The obtained results enabled that the following tests, of loading and unloading (three specimens from each subgroups of archwires) were performed with maximum activation loadings immediately inferior to the respective yield stress (Fig 3). With this methodology the mechanical properties of clinical interest from the several subgroups of archwires could be calculated, without permanent deformations, which could invalidate the tests. On the testing, it were obtained the curves that allowed to determine the stress applied on the wire $(\mathrm{MPa})$ versus the deformation (mm).

All tests of resistance to traction were performed at $37 \pm 1^{\circ} \mathrm{C}$ (average oral temperature) to point the possible shape memory effect (SME), according to methodology of Gravina et al. ${ }^{12}$ The temperature was controlled with a precision digital heat meter, calibrated by INMETRO (Fig 1C). The testing environment in which the archwires were attached to the machine was isolated with styrofoam plates and the temperature was kept constant $\left(\cong 37^{\circ} \mathrm{C}\right)$ using three lamps of 60 watts. The lamps were used to simulate a greenhouse, so the temperature could be controlled through a thermostat (Fig 1C).

Every force-bending curve is constituted of a large number of points, and each one of them is numerically

Table 1 - Orthodontic archwires used in this work

\begin{tabular}{|c|c|c|c|}
\hline \multicolumn{2}{|c|}{ I - SUPERELASTIC GROUP (36 archwires) } & \multicolumn{2}{|c|}{ II - HEAT-ACTIVATED GROUP (24 archwires) } \\
\hline GAC & 6 NiTi (REF. 03-018-53T) & GAC Sentalloy & 6 NiTi (REF. 02-511-132) \\
\hline TP Reflex & 6 NiTi (REF.381-264) & TP Reflex & 6 NiTi (REF. 381-825) \\
\hline Ormco NiTi & $6 \mathrm{NiTi}$ (REF. 219-3204) & Ormco $350 \mathrm{C}$ & 6 CuNiTi (REF. 219-4204) \\
\hline Ormco $27^{\circ} \mathrm{C}$ & 6 CUNiTi (REF. 205-0048) & Unitek Nitinol & $6 \mathrm{NiTi}(\mathrm{REF} .4286-981)$ \\
\hline Masel Elastinol & $6 \mathrm{NiTi}$ (REF. 4828-018) & & \\
\hline Morelli & $6 \mathrm{NiTi}$ (REF. 50.70.014) & & \\
\hline
\end{tabular}
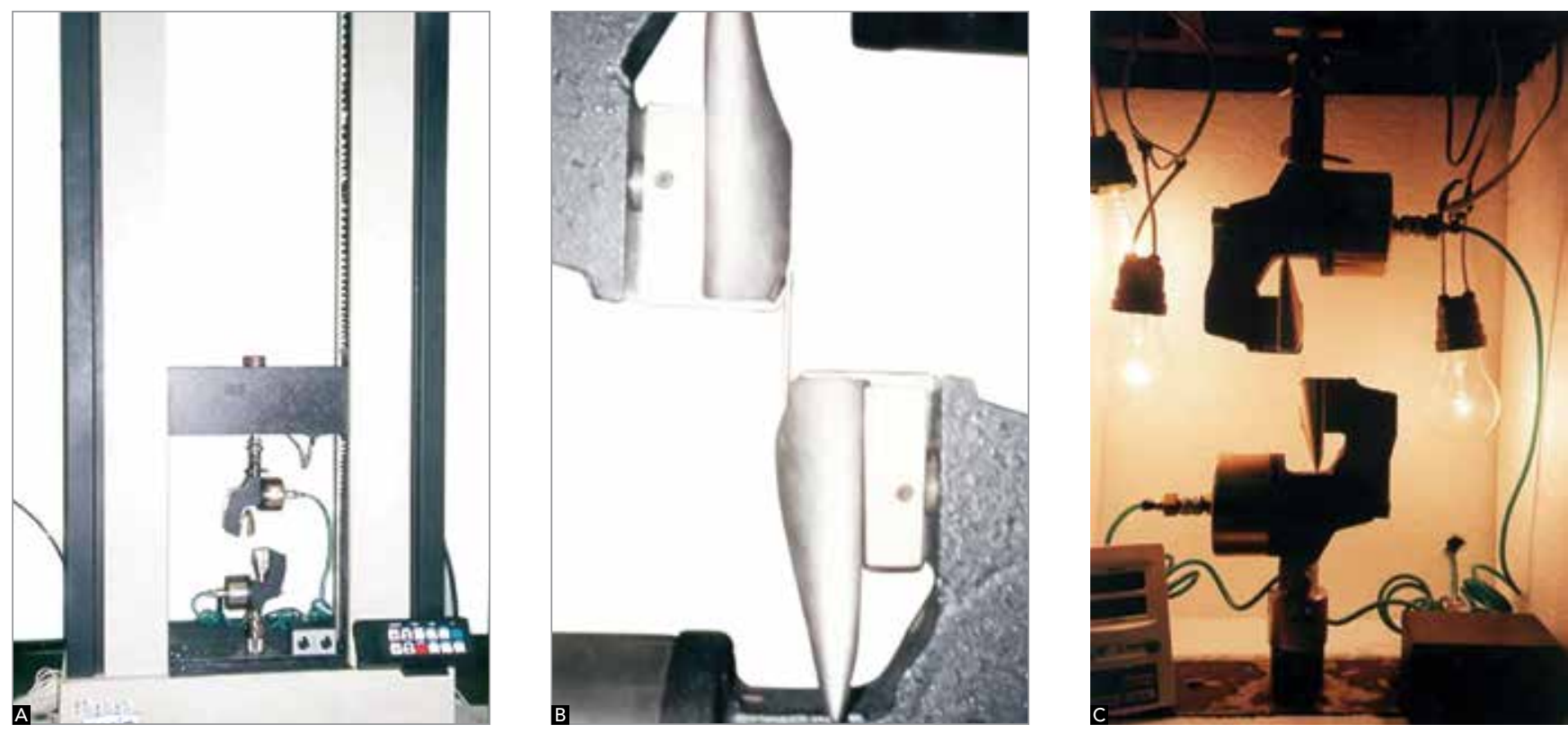

Figure 1 - A) Machine used on the performance of traction resistance tests, B) Detail of the wire tied by its ends to the machine's nails, C) Device used on the performance of tests at oral temperature $\left(37^{\circ} \mathrm{C}\right)$. 
represented by a value where the ordinate (y axis) express the applied force ( $\mathrm{MPa}$ ) and the abscissa ( $\mathrm{x}$ axis) express the deformation occurred ( $\mathrm{mm}$ ). To calculate the mechanical properties of the several subgroups of archwires, all points component of the curve, obtained during performance of the tests, by the program Tesc 3.04 (São José dos Pinhais, PR, Brasil), were exported to Microsoft Excel (Microsoft Corporation ${ }^{\circledR}$, Redmond, WA, USA). From this on, the curves were obtained on Excel (Fig 2A) and the mechanical properties were calculated (Fig 2B) and, statistically analyzed to verify the inter-groups differences (significance) as for the maximum break stress, yield stress, percentage of deformation on constant baselines of deactivation, loadings released during deactivations, permanent deformations and resilience. For so, it were used the analysis of variance (ANOVA) and the Tukey test, both parametric tests, through OriginPro 7.0 and Tesc 3.04 (São José dos Pinhais, PR, Brasil), developed for Windows.

\section{RESULTS}

Results are shown in Table 1.

\section{DISCUSSION}

Several types of laboratorial tests were suggested on the attempt to obtain the mechanical properties of orthodontic archwires, from the test of resistance to traction ${ }^{27,28,29}$ to the flexion and bending tests. ${ }^{3,28}$ In 1977, the American Dental Association (ADA) released a specification ${ }^{18}$ to standardize the laboratorial tests for classification of orthodontic archwires, being chosen the flexion and bending tests. However, the obtained results were controversial in relation to the test of resistance to traction, especially, as for the
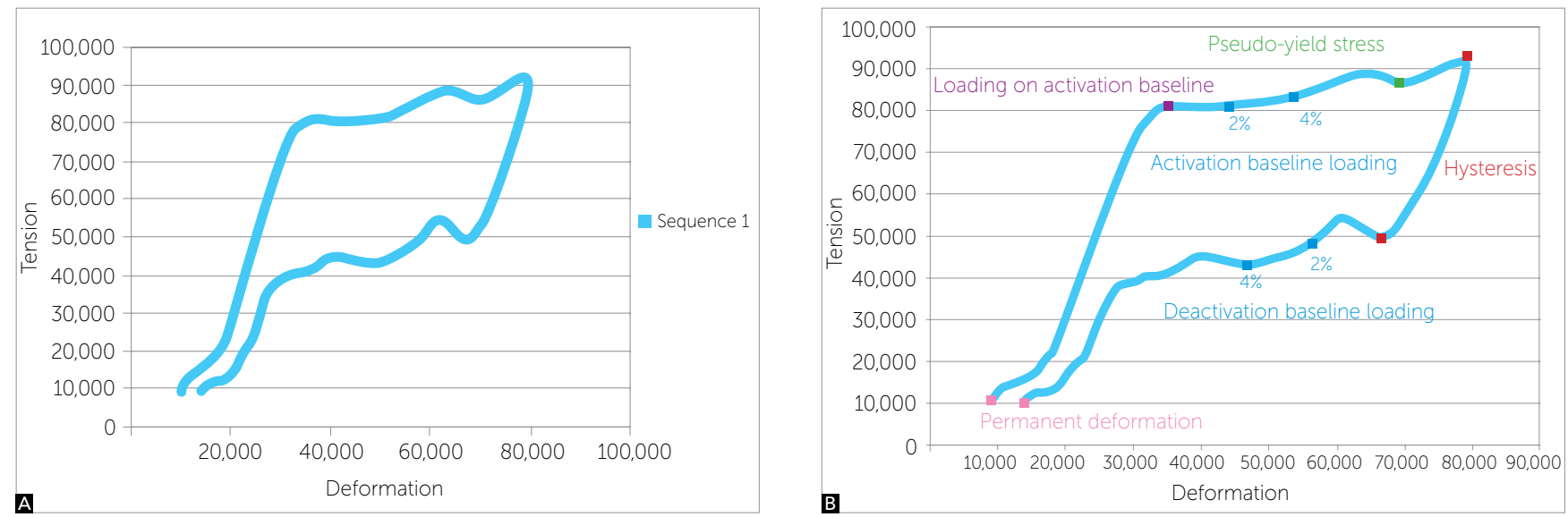

Figure 2 - A) Curve initially obtained on Microsoft Excel. B) Mechanical properties obtained from the curves.

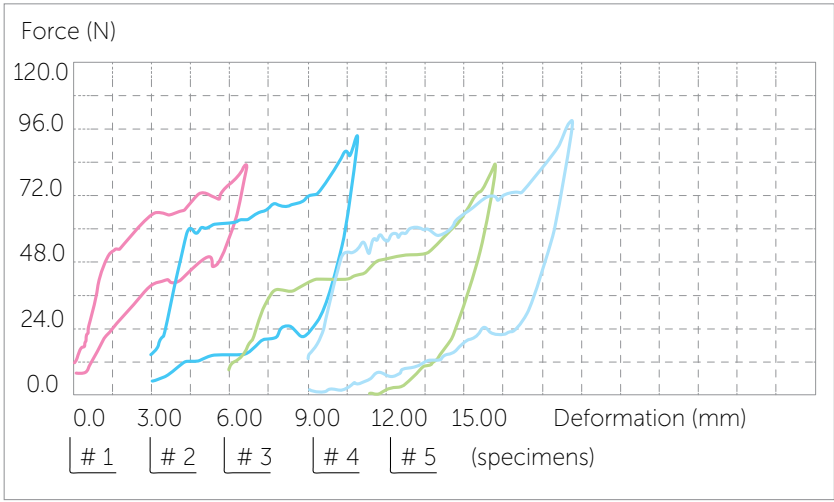

Figure 3 - Stress-strain curve obtained on the tests of heat-activated NiTi and CUNiTi archwires during their loading until their respective limits of flow followed by unloading. 
Table 1 - Values obtained for mechanical properties of the subgroups of tested archwires, where similar symbols indicate similar statistics.

\begin{tabular}{|c|c|c|c|c|c|c|c|c|c|c|}
\hline \multirow[b]{2}{*}{$\begin{array}{l}\text { Mechanical } \\
\text { properties }\end{array}$} & \multicolumn{10}{|c|}{ Mean } \\
\hline & $\begin{array}{c}\text { GAC } \\
\text { NiTi Super }\end{array}$ & $\begin{array}{c}\text { TP } \\
\text { NiTi Super }\end{array}$ & $\begin{array}{c}\text { Ormco } \\
\text { CuNiTi } 27^{\circ} \mathrm{C}\end{array}$ & $\begin{array}{c}\text { Ormco } \\
\text { NiTi Super }\end{array}$ & $\begin{array}{c}\text { Masel } \\
\text { NiTi Super }\end{array}$ & $\begin{array}{c}\text { Morelti } \\
\text { NiTi Super }\end{array}$ & $\begin{array}{c}\text { GAC } \\
\text { NiTi Heat }\end{array}$ & $\begin{array}{c}\text { TP } \\
\text { NiTi Heat }\end{array}$ & $\begin{array}{c}\text { Ormco } \\
\text { CuNiTi } 35^{\circ} \mathrm{C}\end{array}$ & $\begin{array}{l}\text { Unitek } \\
\text { NiTi Heat }\end{array}$ \\
\hline $\begin{array}{c}\text { Maximum } \\
\text { break stress } \\
\text { (MPa) }\end{array}$ & $\begin{array}{c}1447.67 \\
\text {. }\end{array}$ & $\begin{array}{c}1432.49 \\
\text {. }\end{array}$ & $\begin{array}{c}1458.68 \\
\text {. }\end{array}$ & $\begin{array}{c}1286.31 \\
+\end{array}$ & $\begin{array}{c}1267.45 \\
+\end{array}$ & $\begin{array}{c}1523.25 \\
\#\end{array}$ & $\begin{array}{c}1415.13 \\
\text {. }\end{array}$ & $\begin{array}{c}1171.78 \\
\bullet\end{array}$ & $\begin{array}{c}1444.03 \\
\text {. }\end{array}$ & $\begin{array}{c}1011.44 \\
\circ\end{array}$ \\
\hline $\begin{array}{l}\text { Yield stress } \\
\text { (MPa) }\end{array}$ & $\begin{array}{c}604.44 \\
\text { # }\end{array}$ & $\begin{array}{c}546.66 \\
\text {. }\end{array}$ & $\begin{array}{c}450.00 \\
\circ\end{array}$ & $\begin{array}{c}555.00 \\
\text {. }\end{array}$ & $\begin{array}{c}455.60 \\
\circ\end{array}$ & $\begin{array}{c}653.55 \\
\#\end{array}$ & $\begin{array}{c}530.00 \\
\text {. }\end{array}$ & $\begin{array}{c}454.44 \\
\circ\end{array}$ & $\begin{array}{c}438.88 \\
\circ\end{array}$ & $\begin{array}{c}448.36 \\
\circ\end{array}$ \\
\hline $\begin{array}{c}\text { Deformation } \\
\text { deact. bas. (\%) }\end{array}$ & $\begin{array}{c}8.23 \\
\circ\end{array}$ & $\begin{array}{c}7.64 \\
\circ\end{array}$ & $\begin{array}{c}8.84 \\
\circ\end{array}$ & $\begin{array}{c}8.64 \\
\circ\end{array}$ & $\begin{array}{c}12.83 \\
\#\end{array}$ & $\begin{array}{c}12.32 \\
\#+\end{array}$ & $\begin{array}{l}9.56 \\
+^{\circ}\end{array}$ & $\begin{array}{c}7.61 \\
\circ\end{array}$ & $\begin{array}{c}8.88 \\
\circ\end{array}$ & $\begin{array}{c}12.84 \\
\#\end{array}$ \\
\hline $\begin{array}{c}\text { Force }(\mathrm{N}) \\
\text { deactivation } \\
\text { baseline }\end{array}$ & $\begin{array}{c}27.62 \\
\text {. }\end{array}$ & $\begin{array}{c}27.81 \\
\text {. }\end{array}$ & $\begin{array}{c}11.53 \\
\circ\end{array}$ & $\begin{array}{c}35.56 \\
\#\end{array}$ & $\begin{array}{c}16.91 \\
+\end{array}$ & $\begin{array}{c}41.70 \\
\#\end{array}$ & $\begin{array}{c}3.71 \\
\circ\end{array}$ & $\begin{array}{c}0.95 \\
\bullet\end{array}$ & $\begin{array}{c}29.82 \\
\text {. }\end{array}$ & $\begin{array}{c}7.59 \\
\circ\end{array}$ \\
\hline $\begin{array}{c}\text { \% perm. } \\
\text { deformation }\end{array}$ & $\begin{array}{c}6.64 \\
\circ\end{array}$ & $\begin{array}{c}4.65 \\
\circ\end{array}$ & $\begin{array}{c}10.22 \\
\circ\end{array}$ & $\begin{array}{c}12.41 \\
\circ\end{array}$ & $\begin{array}{c}4.34 \\
\circ\end{array}$ & $\begin{array}{c}6.29 \\
\circ\end{array}$ & $\begin{array}{c}17.40 \\
{ }^{\circ}+\end{array}$ & $\begin{array}{c}72.67 \\
\#\end{array}$ & $\begin{array}{c}8.80 \\
\circ\end{array}$ & $\begin{array}{c}28.52 \\
+\end{array}$ \\
\hline
\end{tabular}

Similar symbols indicate statistical similarities. Heat = heat-activated. Super = superelastic.

values found for the elasticity module. Rantley et $\mathrm{al}^{3}$ and Asgharnia and Brantley, ${ }^{2}$ criticized the precision of the tests suggested by ADA, especially for archwires of gauge lower than 0.020 -in, choosing the tests of resistance to traction as the most reliable to obtain the materials mechanical properties, which explains the choice in this present work.

Analyzing the data on Table 2, representative of the mean values for maximum break stress $(\mathrm{N})$ of the subgroups of tested archwires, it was possible to find that the superelastic NiTi archwires by Morelli presented maximum resistance to fracture, for resistance to traction, statistically superior to all others. Among the archwires that presented the lowest resistance to traction are the heat-activated NiTi archwires by Unitek, followed by the heat-activated NiTi archwires by TP. It is also noticed that even for archwires that presented lower fracture loadings, they were extremely high when compared to the clinically used. ${ }^{4,16}$ This way, it could be presumed that none of the tested archwires would be clinically used with risk of fracture.

In relation to the yield stress of the NiTi and $\mathrm{Cu}-$ $\mathrm{NiTi}$ archwires, it was observed that, initially, the stress and deformation were proportional and abided Hooke's law $(\sigma=\mathrm{E} \times \varepsilon)$. From this on, the deformation did not increase proportionally to the stress increase. On the contrary, the stress was kept constant while the deformation increased (constant baseline of activation, Fig 2B). Such baseline represents the pseudoplastic deformation behavior, since, when the loading was removed, the metal did not present expressive permanent or residual deformation, being capable to return to its initial configuration. This behavior is clinically favorable, for constant forces would be supposedly accumulated as the wire was activated. In the present work it was considered the loadings corresponding to the end of the constant baselines of activation as equivalent to the yield stress of the tested archwires (Fig 2B).

It was observed that, generally, the superelastic $\mathrm{NiTi}$ archwires presented superior yield stress than the heat-activated (Table 2). Among the archwires that presented the highest yield stress, are the superelastic NiTi by Morelli and by GAC, and they suffered the highest stress, for resistance to traction, before permanently deform. It was also observed that the heat activate $\mathrm{CuNiTi} 35^{\circ} \mathrm{C}$ archwires by Ormco were the ones that presented the lowest yield stress and consequently the lowest work limits, meeting the report by Sachdeva, ${ }^{25}$ who asserted that the $\mathrm{CuNiTi}$ archwires would be more resistant to permanent deformation and would show better elastic recovery. 
Regarding the percentage of deformation on constant baselines of deactivation (in relation to original length of $50 \mathrm{~mm}$ archwires) it was observed that the superelastic NiTi archwires by Masel and heat-activated archwires by Unitek were the ones that presented, statistically, the highest values (Table 2). Regarding the $\mathrm{NiTi}$ archwires with addition of copper $\left(\mathrm{CuNiTi} 27^{\circ} \mathrm{C}\right.$ and $35^{\circ} \mathrm{C}$ ), it was observed percentage of deformation statistically inferior on baselines of deactivation in relation to heat-activated NiTi archwires by Unitek and superelastic archwires by Masel and by Morelli (Table 2). Such results do not confirm the findings by Sachdeva, ${ }^{25}$ who asserted that $\mathrm{CuNiTi}$ archwires, for presenting reduced hysteresis, would present their plateaus constant of loadings superior in extension, during the unloading, favorable factors to tooth movement. On the other hand, the percentage of deformation found for CuNiTi archwires, on constant baselines of deactivation, were statistically similar to the presented by the superelastic NiTi archwires by GAC, TP and Ormco, which presented the lowest percentage of deformation among all tested archwires (Table 2).

Among all mechanical properties of orthodontic archwires, the strength released during deactivation is the one that expresses the most and it relates to the archwires clinical behavior. It was observed that, generally, the heat-activated NiTi archwires presented slighter loadings of deactivation in relation to superelastic. Among superelastic NiTi archwires, the CuNiTi $27^{\circ} \mathrm{C}$ by Ormco were the ones that presented the slightest deactivation loadings. Among the heat-activated NiTi archwires, the CuNiTi $35^{\circ} \mathrm{C}$ were the ones that presented the highest deactivation loadings, being statistically similar to the ones presented by the superelastic NiTi archwires by GAC and by TP (Table 2). Such results meet the report by Sachdeva ${ }^{25}$ who asserted that the $\mathrm{CuNiTi}$ archwires, for having lower elasticity module, would suffer deformations similar to the conventional superelastic and heat-activated NiTi archwires, before lower activation loadings. Among the archwires that presented the highest deactivation loadings are the superelastic by Morelli and by Ormco, being statistically superior to the presented by the other tested NiTi and $\mathrm{CuNiTi}$ archwires. Among the archwires that presented the lowest deactivation loadings are the heatactivated by GAC and by Unitek and the superelastic
$\mathrm{CuNiTi} 27^{\circ} \mathrm{C}$ by Ormco, with statistically similar deactivation loadings. Although the heat-activated NiTi archwires by TP presented slight deactivation loadings, they presented significant percentage of permanent deformation on most unloading tests at $37^{\circ} \mathrm{C}$, which would disable its mechanical properties and explain the obtainment of such loadings.

When compared the $\mathrm{CuNiTi} 27^{\circ} \mathrm{C}$ and $35^{\circ} \mathrm{C}$ archwires, it was observed that the first presented deactivation forces of about $1 / 3$ of the presented by the last ones. This data meets the recommendations from the manufacturer (Ormco Corp.), which supported by the works of Sachdeva, ${ }^{25}$ stated that the $\mathrm{CuNiTi} 27^{\circ} \mathrm{C}$ archwires should be used in cases where high and biologically acceptable loadings were required and the $\mathrm{CuNiTi} 35^{\circ} \mathrm{C}$ archwires should be used to obtain mild loadings. The result of the present work are in agreement to the findings by Dalstra and Melsen, ${ }^{6}$ which asserted that some patients reported greater discomfort when using the $\mathrm{CuNiTi} 40^{\circ} \mathrm{C}$ archwires, when ingesting warm mouth rinses, in relation to the $\mathrm{CuNiTi} 27^{\circ} \mathrm{C}$ archwires, since the loading generated by those, during unloading, would be superior to the produced by these.

In the present work, it was demonstrated that the loading released on constant baselines of deactivation were extremely high when compared to the ones used intraorally, which should vary between 15 and 500 gf. $^{21,23}$ From this principle, in the present work, only the heat-activated NiTi archwires by GAC could be clinically used since they released loading corresponding to $3.71 \mathrm{~N}$ (371 gf), being the other loadings released by the tested $\mathrm{NiTi}$ and $\mathrm{CuNiTi}$ archwires, above this baseline (Table 2). Gurgel et $\mathrm{al}^{13}$ asserted, however, that although the tests of resistance to traction, bending, torsion and deflection do not completely reproduce the clinical situation, they establish adequate values for comparison between archwires of similar or different metallic alloys. Ibe and Segner, ${ }^{14}$ however, emphasized that the comparison or extrapolation of values obtained in laboratorial tests, to the clinically obtained, should be done very carefully. ${ }^{14}$

The results of the present work were different from the ones found by Fisher-Brandies et al, ${ }^{10}$ which through the deflection test in 3 points, reported that the $\mathrm{CuNiTi} 35^{\circ} \mathrm{C}$ archwires (Ormco) and the Neo Sentalloy F80 (GAC), both heat-activated, presented plateaus of unloading under lower loadings related 
to the Rematitan Lite (Dentaurum) and Titanol SE S (Forestadent) archwires, both superelastic. In the present work, the $\mathrm{CuNiTi} 35^{\circ} \mathrm{C}$ archwires presented deactivation loadings statistically superior to the other heat-activated NiTi archwires and similar to the superelastic NiTi archwires by GAC and TP (Table 2).

Still contrary to the results obtained in the present work, Gurgel et al, ${ }^{13}$ through artificial models of dental arches, showed that the CuNiTi $35^{\circ} \mathrm{C}$ (Ormco) and Neo Sentalloy F200 (GAC) archwires, presented intermediate deactivation loadings, without statistical difference between them, while the Elastinol $35^{\circ} \mathrm{C}$ (Masel), heat-activated NiTi (Morelli) and Nitinol heat-activated (3M Unitek) archwires presented the slightest deactivation loadings. It is worth emphasizing however that Gurgel et $\mathrm{a}^{13}$ used the Neo Sentalloy F200, while the authors of this present work used the Neo Sentalloy F80, both by GAC. In relation to the $\mathrm{CuNiTi} 27^{\circ} \mathrm{C}$ archwires (Ormco), Gurgel et al ${ }^{13}$ asserted that they presented deactivation loadings statistically higher to the presented by heat-activated archwires by Unitek and CuNiTi $35^{\circ} \mathrm{C}$ by Ormco, ${ }^{13}$ not confirming the results of the present work (Table 2).

On the other hand, the results of the present work were consistent with the found by Sakima et al, ${ }^{26}$ which through Force System Identification (FSI), showed that the CuNiTi $40^{\circ} \mathrm{C}$ (Ormco) and Neo Sentalloy F200 (GAC) archwires were the ones that presented the unloading plateaus under the lowest loadings, followed by $\mathrm{CuNiTi} 35^{\circ} \mathrm{C}$ archwires (Ormco); while the superelastic NiTi by Ormco, presented plateaus of unloading under the highest loadings, becoming the most inflexible archwires in this work. Also in the present work the heat-activated NiTi archwires by GAC presented the slightest deactivation loadings among the tested archwires and the $\mathrm{CuNiTi} 35^{\circ} \mathrm{C}$ archwires presented deactivation loadings statistically lower to the presented by superelastic NiTi archwires by Ormco, which presented the second highest deactivation loadings among the tested archwires.

Table 2 shows that, generally, the superelastic $\mathrm{NiTi}$ archwires presented lower percentage of permanent deformations in relation to the heat activate $\mathrm{NiTi}$ archwires. Among the tested superelastic NiTi and CuNiTi archwires it were not observed statistically significant differences between the percentage of permanent deformation. Among the heat-activated
NiTi archwires, it was observed that the ones by TP presented the highest percentage of permanent deformation in the work, statistically superior to the ones presented by all other tested NiTi and CuNiTi archwires. However, it was observed, in a pilot trial, that the mean percentage of permanent deformation was reduced from 72.67 to $28.50 \%$, with the increase of testing temperature from 37 to $40^{\circ} \mathrm{C}$. As these archwires were not subjected to activation loadings higher than their respective pseudo-yield stress, which could have invalidated the tests and generated permanent deformations, it was concluded that the transition temperature of the heat-activated $\mathrm{NiTi}$ archwires by $\mathrm{TP}$ was superior to $37^{\circ} \mathrm{C}$. For this reason, such archwires presented deactivation loadings extremely reduced.

Confirming the results of the present work, Parvizi and Rock ${ }^{20}$ asserted that the complete recovery of the initial configuration after unloading is not always obtained for superelastic and heat-activated $\mathrm{NiTi}$ archwires, being kept between baselines of 89 and $94 \% .{ }^{20}$ The present work showed that, at $37^{\circ} \mathrm{C}$, all tested $\mathrm{NiTi}$ and $\mathrm{CuNiTi}$ archwires presented some degree of permanent deformation, being significantly expressive only for heat-activated NiTi archwires by TP (Table 2). Among the tested superelastic NiTi and $\mathrm{CuNiTi}$ archwires, the complete recovery of the initial configuration was kept between 88 and 96\%, while for heat activated NiTi archwires, it was kept between 71 and $82 \%$ (Table 2).

The results of the present work were against the findings by Damon, ${ }^{7}$ who proved the efficiency of the application of slight loadings during the phase of tooth alignment with insertion of the $\mathrm{CuNiTi} 35^{\circ} \mathrm{C}$ wire (Ormco). According to the same author, the word "system" (Damon system) would be used to define the combination of self-ligating brackets and high technology orthodontic archwires, carefully selected so the applied loading is kept within the great levels of force or biozone. He recommended for such purpose, the sequential use of $\mathrm{CuNiTi} 35^{\circ} \mathrm{C}$ orthodontic arches of diameter 0.014-in, $0.014 \times 0.025$-in and $0.018 \times 0.025$-in, being the reduction of the generated attrition the key to a more efficient and fast orthodontic treatment, with reduction of up to $70 \%$ on the number of necessary visits to orthodontists. ${ }^{7}$ In the present work, the $\mathrm{CuNiTi} 35^{\circ} \mathrm{C}$ archwires were the less recommended for clinical use, among the heat activated, because of the loadings released during 
deactivation and of the percentage of deformation of the unloading baselines. It is recommended, however, a new work that evaluates the attrition of such archwires in relation to the other superelastic and heat activated NiTi and CuNiTi archwires.

\section{CONCLUSION}

1) Among the tested superelastic NiTi and CuNiTi archwires, the $\mathrm{CuNiTi} 27^{\circ} \mathrm{C}$ presented mechanical properties superior to the others, releasing lower deactivation loadings. The superelastic NiTi archwires by
Morelli were the less recommended for use, for presenting deactivation loadings statistically superior to the presented by the other tested archwires.

2) Among the tested heat activated $\mathrm{NiTi}$ and CuNiTi archwires, the ones by GAC and Unitek presented mechanical properties superior to the others, releasing lower deactivation loadings and presenting superior percentage of deformation on the deactivation baselines. In relation to the $\mathrm{CuNiTi} 35^{\circ} \mathrm{C}$ archwires, they did not present mechanical properties, under traction resistance, that justified its clinical choice.
1. Andreasen GF, Morrow RE. Laboratory and clinical analysis of Nitinol wire. Am J Orthod. 1978:73 (2) :142-51.

2. Asgharnia MK, Brantley WA. Comparison of bending and tension tests for orthodontic wires. Am J Orthod. 1986:89 (3) :228-36.

3. Brantley WA, Augat WS, Myers CL, Winders RV. Bending deformation studies of orthodontic wires. J Dent Res. 1978:57 (4) :609-15.

4. Burstone CJ, Goldberg AJ. Beta titanium: a new orthodontic alloy. Am J Orthod. 1980;77 (2): 121-32

5. Cobb NW 3rd, Kula KS, Phillips C, Proffit WR. Efficiency of multi-strand steel, superelastic $\mathrm{Ni}$-Ti and ion-implanted $\mathrm{Ni}-\mathrm{Ti}$ archwires for initial alignment. Clin Orthod Res. 1998;1 (1) :12-9

6. Dalstra M, Melsen B. Does the transition temperature of Cu-NiTi archwires affect the amount of tooth movement during alignment? Orthod Craniofac Res. 2004;7 (1) :21-5.

7. Damon DH. The Damon low-friction bracket: a biologically compatible straight-wire system. J Clin Orthod. 1998;32 (11):670-80

8. Evans TJW, Durning P. Orthodontic products update. Aligning archwires. The shape of things to come? A forth and fifth phase of force delivery. $\mathrm{Br} \mathrm{J}$ Orthod. 1996:23 (3) :269-75.

9. Evans TJ, Jones ML, Newcombe RG. Clinical comparison and performance perspective of three aligning arch wires. Am J Orthod Dentofacial Orthop. 1998;114 (1) :32-9.

10. Fischer-Brandies H, Es-Souni M, Kock N, Raetzke K, Bock O. Transformation behavior, chemical composition, surface topography and bending properties of five selected 0.016" X 0.022" NiTi archwires. J Orofac Orthop. 2003:64 (2) :88-99.

11. Gravina MA, Motta TS, Almeida AAO, Quintão CCA. Fios ortodônticos: propriedades mecânicas relevantes e aplicação clínica. Rev Dental Press Ortod Ortop Facial. 2004;9 (1) :113-28.

12. Gravina MA, Quintão CA, Koo D, Elias CN. Mechanical properties of nickel titanium and steel alloys under stress-strain test. Korean J Orthod. 2003;33 (6) :465-74.

13. Gurgel JA, Kerr S, Powers JM, LeCrone V. Force-deflection properties of superelastic nickel-titanium archwires. Am J Orthod Dentofacial Orthop. 2001;120 (4):378-82

14. Ibe DM, Segner D. Superelastic materials displaying different force levels within one archwire. J Orofac Orthop. 1998:59 (1):29-38.
15. Kapila S, Sachdeva R. Mechanical properties and clinical applications of orthodontic wires. Am J Orthod Dentofacial Orthop. 1989;96 (2) :100-9

16. Miura F, Mogi M, Ohura Y, Hamanaka H. The super-elastic property of the Japanese NiTi alloy wire for use in orthodontics. Am J Orthod Dentofacial Orthop. 1986:90 (1) :1-10.

17. Mohlin B, Müller H, Odman J, Thilander B. Examination of Chinese Ni-Ti wire by a combined clinical and laboratory approach. Eur J Orthod. 1991;13 (5) 386-91.

18. Council on Dental Materials and Devices. New American Dental Association specification no. 32 for orthodontic wires not containing precious metals J Am Dent Assoc. 1977:95:1169-71.

19. O'Brien WJ, Ryge G. An outline of dental materials and their selection. Philadelphia: W.B. Saunders; 1973.

20. Parvizi F, Rock WP. The load/deflection characteristics of thermally activated orthodontic archwires. Eur J Orthod. 2003:25 (4) :417-21.

21. Proffit W. Contemporary orthodontics. St. Louis: Mosby; 1986

22. Quintão CCA, Elias CN. Fios utilizados em fase inicial de tratamento ortodôntico: propriedades mecânicas e desempenho clínico [tese]. Rio de Janeiro (RJ) : Universidade Federal do Rio de Janeiro; 2000.

23. Rock WP, Wilson $\mathrm{HJ}$. Forces exerted by orthodontic aligning archwires. $\mathrm{Br} \mathrm{J}$ Orthod. 1988:15 (4) :255-9

24. Rygh P. Orthodontic forces and tissue reaction. In: Thilander B, Rönning $\bigcirc$ Introduction to orthodontics. Stockholm: Tandläkarförlaget; 1985. p. 205-24

25. Sachdeva R. Sure-Smile: Technology-driven solution for orthodontics. Tex Dent J. 2002:119 (7) :608-15

26. Sakima MT, Dalstra M, Melsen B. How does temperature influence the properties of rectangular nickel-titanium wires? Eur J Orthod. 2006;28 (3) :282-91.

27. Souza SA. Ensaios mecânicos de materiais metálicos. 3 ạ ed. São Paulo: Edgard Blücher; 1974

28. Thurow RC. Edgewise orthodontics. 3rd ed. Saint Louis: Mosby; 1979

29. Twelftree CC, Cocks GJ, Sims MR. Tensile properties of orthodontic wires. Am J Orthod. 1977:72 (6) :683-7.

30. West AE. A clinical comparison of two initial aligning archwires [thesis] Cardiff: University of Wales; 1992 